\title{
RADICAL THACIFR
}

A SOCIALIST, FEMINIST, AND ANTI-RACIST JOURNAL ON THE THEORY AND PRACTICE OF TEACHING

\section{In Memoriam:}

Pepi Leistyna

by Editorial Board

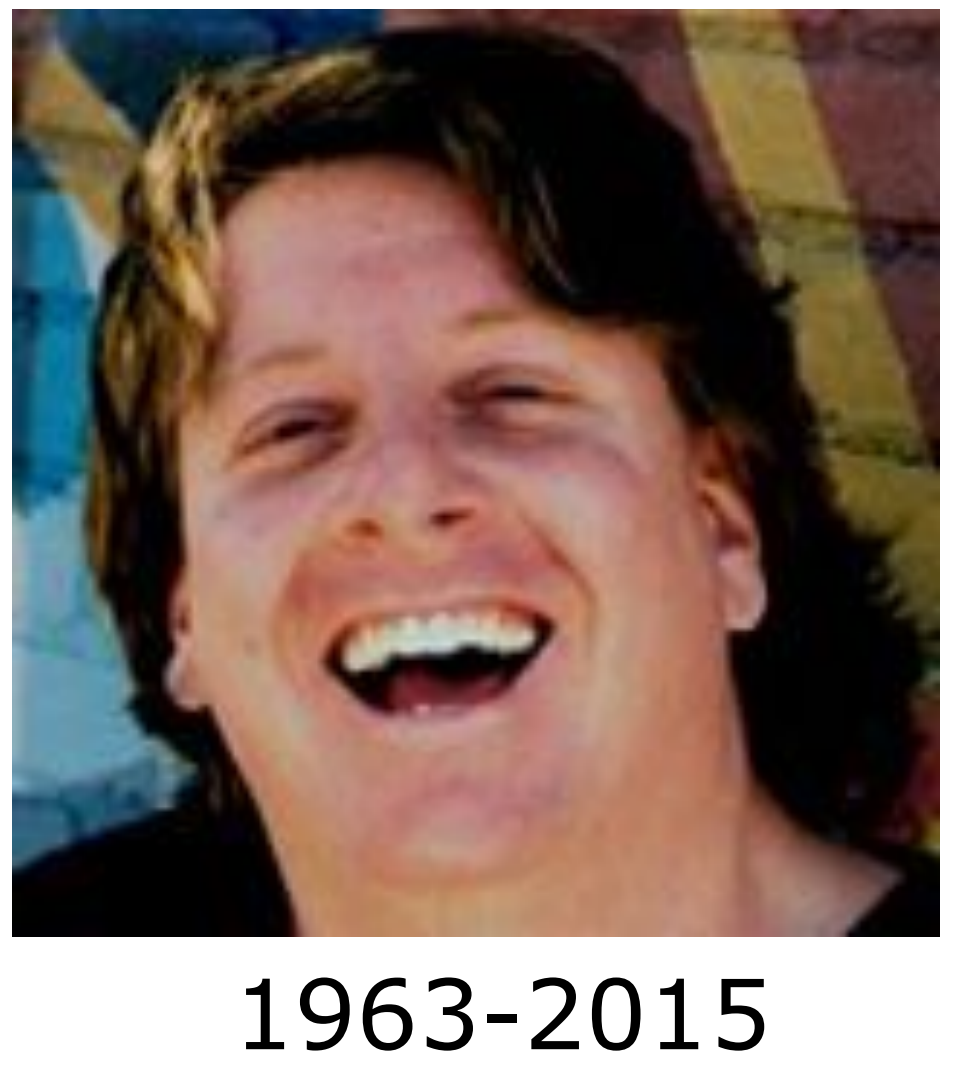


We mourn our Radical Teacher colleague, beloved educator, admired scholar and friend, Pepi Leistyna. Pepi's work and passionate commitment to progressive politics are our cherished legacy, joined with many others.

Pepi's students' blog comments regarding news of his death are heartfelt in their grief but also in love and admiration for him-for his compassion, wisdom, vast knowledge, and wit. The passion which fed his teaching also nourished his writing, lectures, his film Class Dismissed: How TV Frames the Working Class, which won the Studs Terkel Award for Media and Journalism (2007), and his winning the Peace Maker Award for photography in Palestine (2013). Teaching, researching, and activism were all of a piece for Pepi. He was a founding member of the International Institute for Critical Pedagogy and Transformative Leadership, and published widely, including the books Breaking Free: The Transformative Power of Critical Pedagogy, Presence of Mind: Education and the Politics of Deception, Cultural Studies: From Theory to Action. Pepi brought to Radical Teacher the same unflagging energy and commitment to social justice that inspired all he did. Among other things he compiled for Radical Teacher an excellent filmography on social class (RT 81) and he co-edited the cluster "Teaching Post-Colonial Literatures in the Age of Empire" (RT 82).

Pepi was Professor of Applied Linguistics Graduate Studies at the University of Massachusetts-Boston, where he taught courses in language acquisition, critical pedagogy, cultural studies, and media literacy, and directed the Center for World Language and Cultures.

Like his students, we at Radical Teacher remember with affection Pepi's ability to connect our humanity and joy to the cause of social justice. One of his students includes in his blog highlight quotes from Pepi's teaching:

- What if I came in wearing a dress?

- So what If I like to wear deodorant that smells like flowers?

- If you came here to listen to my clothes, you have the wrong guy.

- There goes Pepi, that raving Marxist. 


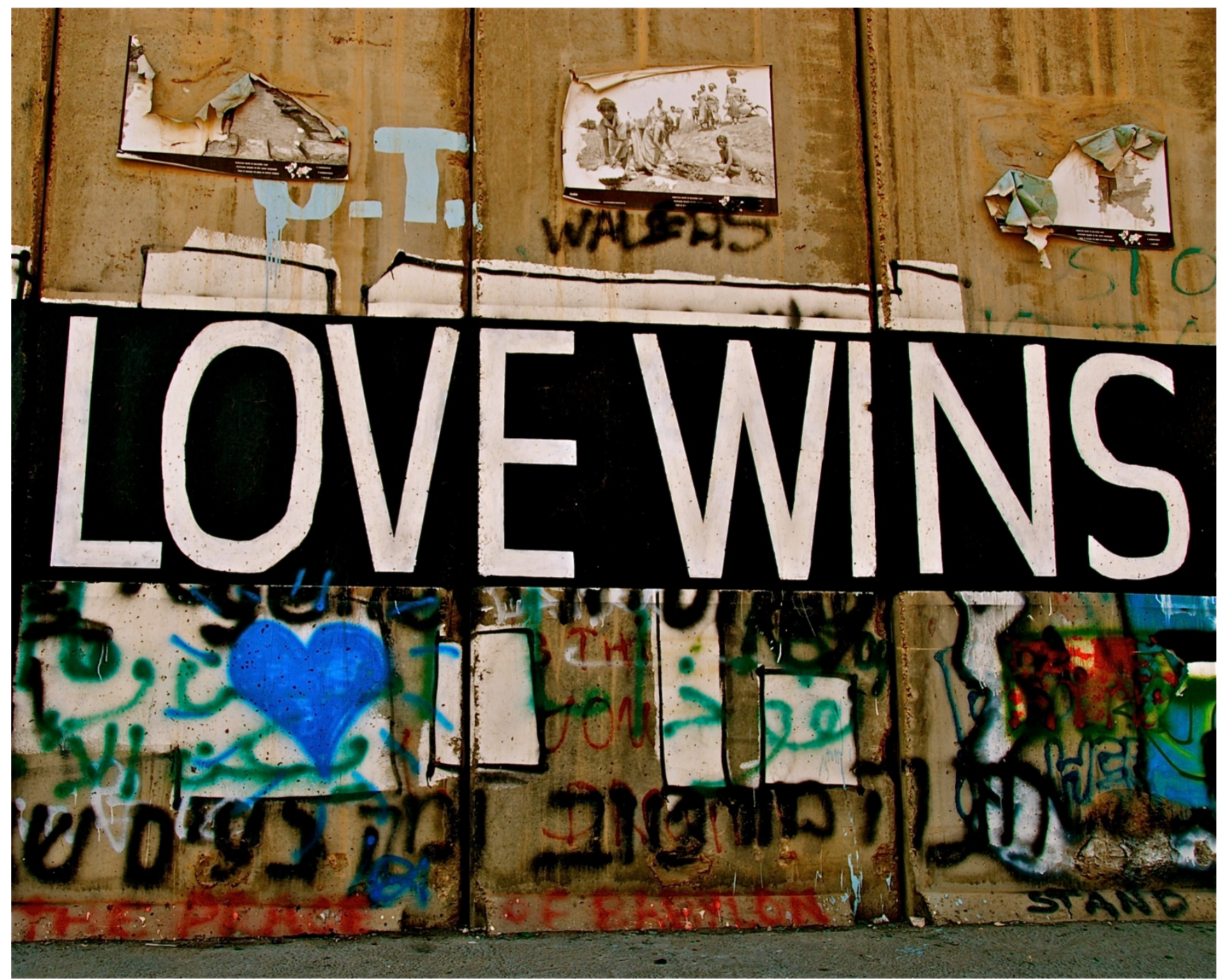

PHOTO TAKEN IN PALESTINE BY PEPI LEISTYNA

\section{(cc) EY-NG-ND}

ULIS D-Sork
This work is licensed under a Creative Commons Attribution-Noncommercial-No Derivative Works 3.0 United States License.

This journal is published by the University Library System of the University of Pittsburgh as part of its D-Scribe Digital Publishing Program, and is cosponsored by the University of Pittsburgh Press. 